\title{
The Effects of Cross Cultural Work Force Diversity on Employee Performance in Egyptian Pharmaceutical Organizations
}

\author{
Abdel Moneim Elsaid, Associate Professor \\ Business Administration Department, Faculty of Commerce \\ Ain Shams University, Cairo, Egypt \\ E-mail: drelsaid78@yahoo.com
}

Received: November 22, 2012

Accepted: December 10, 2012

Online Published: December 11, 2012

doi:10.5430/bmr.v1n4p162

URL: http://dx.doi.org/10.5430/bmr.v1n4p162

\begin{abstract}
In today's increasingly rapid changing business environment, countries such as Egypt have changed drastically to accommodate the increasingly diverse work force in most, if not all, of its organizations. The diversity of the work force in Egypt is quite admirable and has been taking an ever increasing trend in the past couple of decades. Nowadays, it is very common to find business professionals whom are simultaneously fluent in several languages, such as English, French, German, and of course Arabic while coming from a highly diverse training and education backgrounds. This study explores the impact of gender, age, and education background on employee performance in the Egyptian Pharmaceutical industry which is renowned to employ highly diversified workforce. The study sample was 300 middle level management positions. Data was collected via self-administered questionnaires methodology. The results indicated that only two variables, gender and education background, were significant in explaining the variance in employee performance when different work force work together, while surprisingly, age diversity does not.
\end{abstract}

Keywords: Egypt, Culture, Gender, Age, Educational background, Diversity

\section{Introduction}

Workplace diversity is a multi-faceted concept that will continue to evolve as more industries, specifically the pharmaceutical industry, move toward both working in and recruiting employees from a global market place. It is argued that this has led to a perception that work force diversity became inevitable and fundamental for sustainable organizational performance. This belief drives corporate managers to embrace and comprehend the concept of work place diversity, its barriers, and benefits. Furthermore, workforce diversity is increasingly recognized and utilized as one of the very important, if not the most important, organizational resources in regards to whether the goal of an organization is to be an employer of choice, to provide excellent customer service, or to maintain a competitive edge. Any business that intends to be successful must have a borderless view and an underlying commitment to ensure that work force diversity is part of its day-to-day business operations (Childs, 2005).

Limited empirical research demonstrated that diversity management can indeed improve organizational outcomes (Kalev, 2006; Ng and Burke, 2005; Pitts, 2009). This study attempts to bridge that gap and argue that the future success of any organization relies on the ability to manage a diverse body of talent that can bring innovative ideas, perspectives, and views to their work. The challenge and problems faced as a result of incorporating work place diversity under one roof can be turned into a strategic organizational asset if organizations are able to capitalize on this melting pot of diverse talents. With the mixture of talents of diverse cultural backgrounds, genders, ages, and lifestyles, an organization can respond to business opportunities more rapidly and creatively, especially in the global area which must be one of the important organizational goals to be attained. Furthermore, Hilary and Elaine (2000) suggested that organizations should embrace diversity in their workforce and work towards achieving it by creating a culture where difference can thrive, rather than working simply for representatives and assimilation. More importantly, if the organizational environment does not support diversity broadly, organizations risk losing talent to competitors. Chan (2009) found that in order to effectively manage workplace diversity, the Human Resource Manager needs to maintain a cross cultural sensitivity competency by changing his/her management philosophy from an ethnocentric view (our way is the best way to do things) to a culturally relative perspective (let's take the best of a 
variety of ways). This shift in mindset has to be ingrained in the management style of Human Resource Managers in their basic management functions.

It is argued that organizations that develop and employ the necessary policies and procedures to attract and retain the best and most qualified employees maintain a competitive advantage among their counterparts and subsequently increase their effectiveness. To achieve success and maintain a competitive advantage, organizations draw on the most important resource, which is the skill set of the workforce. When work force diversity is not managed properly, there will be a potential for higher voluntary employee turnover, difficulty in communication, and destructive interpersonal conflicts. Overall, it will be adversarial to organization's performance, profitability, and needless to mention, reputation. Decades of research on the effects of diversity within teams and small groups indicate that diversity can have negative effects, as well as positives ones (Kochan et al., 2003). Moreover they elaborated that the lack of evidence linking workforce diversity to employee performance may be that the relationship between diversity and the bottom line is more complex than is implied by the popular discussion.

The objective of this study is threefold, first, to identify the factors that affect the workforce diversity towards employee's performance in organizations. Second, to serve as a guideline for the potential new entrants who wish to enter the industry on issues that will need to be considered before starting any business. Third, to study the relationships of gender, age, and education background on overall employee performance in an organization.

\section{Problem Statement}

Understanding the impacts of work force diversity on organizational outcomes, such as organizational performance, employee satisfaction, and voluntary employee turnover, is key organizational sustainability (Sungjoo and Rainey, 2010). Work force diversity is proclaimed as an opportunity for organizations to become more creative, to reach previously untapped markets, and in general to achieve and maintain a competitive advantage (Loriann and Carol, 2007; Cox, 1994; Robinson and Dechant, 1997; Thomas and Ely, 1996). Erasmus (2007) argued that workforce diversity creates conflict and uncertainty in the workforce as management, on average, is not skilled in the discipline of diversity management. As a result, managers do not know how to effectively practice diversity. Employees still make decisions to break the rules with their behavior when it comes to diversity (Victoria and Mary, 2010). According to Kochan et al., (2003), diversity within the work place can evoke an array of emotions as some view diversity as something to be dealt rather than a tool to be used to improve the organization. Even though, many will agree that the results of a diversity-conscious organization add value to the employee and organization, yet research evaluating diversity for the sake of developing methods of interventions does not exist (Dahm, 2003).

\subsection{Research Questions}

The research questions are as follows:

1) What is the relationship between gender and employee performance?

2) What is the relationship between age and employee performance?

3) What is the relationship between education background and employee performance?

4) What is the relationship between workforce diversity and employee performance?

\subsection{Hypothesis}

In this study, employee performance is the dependent variable while gender, age, and education background are the independent variables.

Kochan et al., (2002) argued that employees began to realize and recognize demographic differences such as gender differences affecting the working relationship between employees and their performance. Moreover, Jehn and Werner (1993) measured that diversity had a significant effect on group processes, but the nature of the effect depended on whether the diversity was in gender or not.

H1: There is a significant relationship between gender and employee performance

Winnie (2008) found that youth, on one hand, are more willing to learn new things and accept new ideas and on the other hand, older people who have more life experiences are more mature and possess better problem-solving skills. It is argued that different age groups provide different values for companies and these values can complement each other which improve companies' performance. Furthermore, age heterogeneity on its own has a negative effect on individual productivity (Gellner and Veen, 2009).

$\mathrm{H} 2$ : There is a significant relationship between age diversity and employee performance 
Organizations implement education diversity initiatives in efforts to motivate employees to work effectively with others to achieve organizational goals (Gwendolyn, 2002). An employee's education background can be a significant indicator of their knowledge, skills, and capability. Furthermore, the choice of a specific education major may reflect one's cognitive strength and personality (Holland, 1997). As in functional expertise, dissimilarity in education background seems to have a positive impact on team performance because it fosters a broader range of cognitive skills (Cohen and Bailey, 2001). On the other hand, education background can also negatively affect team performance and social integration in teams (Cohen and Bailey, 2001). Jackson et al., (2005) discovered that wide differences in education background led to an increase in task-related debates among work teams (Jehn et al., 1997). Knight et al., (1999) found that education diversity was negatively related to decision-making consensus in top management teams. It seems that heterogeneous education backgrounds tend to increase the level of discomfort and conflict that may lead to decreased social integration in teams. In other words, education background diversity can have both advantages and disadvantages for employee performances toward organization.

H3: There is significant relationship education background and employee performance

\section{Literature Review}

\subsection{Employee Performance}

Previous research on workplace diversity suggests that diversity can be either detrimental or beneficial for employee performance (Williams and O'Reilly, 1998). For instance, employee diversity is positively associated with creativity and problem-solving skills (Bantel and Jackson, 1989; Jehn et al., 1999) and negatively related with cohesiveness and cooperation (Pelled et al., 1999). Good work force diversity practices in the area of human resources are believed to enhance both employee and organizational performance (Adler, 1986). Furthermore, employee diversity allows increased creativity, a wider range of perspectives, better problem definition, more alternatives and better solutions (Adler, 1986). It is also argued that with decreasing homogeneity in the workforce, it has become crucial for organizations to develop equal opportunities and diversity management policies to maintain the skills of employees with diverse backgrounds in order to protect their competitive position in the market place (Gilbert and Ivancevich, 2000; Shaw, 1993).

Work place diversity generates conflicts between employees. Conflict occurs due to differences of perception, ideas, behaviors, interest, attitudes, religious differences, political differences and unjustified distribution of resources. Conflict is not always negative and does not always create hostilities. It very much depends on how the conflict is handled. If handled properly, it can become a very rich source of development (Kigali, 2006). When corporate managers ignore the conflicts between co-workers, this will result in clashes amongst them. In turn, these clashes will be converted into personal and emotional conflict in the long run and therefore damages the organizational culture, worker morale, and overall organizational performance. It can also lead to a reduction in creativity, innovation, quality, and performance of employees and organizations ultimately leading to negative effects on the team performance (Jehn, 1994, 1995; Amason, 1996; De Dreu and Vande, 1997; Friedman et al., 2000; Michael et al., 2001; Passos and Caetano, 2005).

\subsection{Gender}

We live in a male dominant world, with most cultures around the globe adhering to that notion. Consequently, many organizations prefer to hire men compared to women because men are perceived to have better performance and ability to manage their jobs and women are stereotyped against in those characteristics (Leonard and Levine, 2003; Nkomo, 1992; Heilman et al., 1989). According to Brown (2008) and Carr-Ruffino (2003), significant amount of workforce diversity remains ineffective if gender issues are not first recognized then in turn managed. The challenge is first to successfully overcome the thought that woman are not equal to man. Kossek et al., (2005) found that only $54 \%$ of women are in the workforce worldwide compared to $80 \%$ of men. Nevertheless, according to Kochan et al., (2002), providing an equal job opportunity to women is vital to improve performance of employees in an organization. These societal mandates eliminated formal policies that discriminated against certain classes of workers and raised the costs to organizations that failed to implement fair employment practices. Discrimination on hiring workers based on gender has resulted in a firm's hiring workers who are paid higher wages than alternative workers, but are no more productive (Barrington and Troke, 2001; Becker, 1971). Moreover, Wentling and Rivas (2000) study stated that organizations with diverse workforce provide superior services and tap niche markets because they can understand customers better (Kundu, 2003). 


\subsection{Age}

Age diversity has become an inevitable fact of life in many organizations (Kunze et al., 2011). There are two major theories which explain this relationship; the social identity and self categorization respectively. Individuals are suggested to classify themselves into certain groups on the basis of dimensions that are personally relevant for them according to social identity and self categorization theories (Kunze et al., 2011; Tajfel and Turner, 1986). As a result, individuals tend to favor members of their own group at the expenses of other groups, against which they may both stereotype and discriminate against (Kunze et al., 2011). Gelner and Stephen (2009) argued that age heterogeneity can negatively affect employee productivity due to differences in values and preferences of distinct age groups. It has also been shown that conflicts are particularly frequent in the presence of generation gaps (Gelner and Stephen, 2009; Lau and Murnighan, 2005; Pitcher and Smith 2001).

\subsection{Education background}

Tracy and Sappington (1993) found that employers commonly reject hiring employees whose training, experience, or education is judged to be inadequate. This means that education background is critical to employees' employability level. Employees cannot find a job and perform well without adequate education background. Besides that, Daniel (2009) found that an employee will be more productive depending on the level of his/her education. The more education the individual received, the more productive the worker will be. Moretti (2004) argued that cities with higher percentage of tertiary education level workers will enable individuals of all education level secure higher wages. Glaeser et al., (1995) found that a greater proportion of educated workers in a city translate to higher economic growth.

\section{Research Methodology}

The main objective of this research is to analyze the effect of workforce diversity on employee performance in pharmaceutical organizations. The targeted industry is the local Egyptian pharmaceutical industry. The target population is 300 employees in the middle level management departments of the 5 largest local pharmaceutical companies in Egypt. In this study, sampling frame is irrelevant, thus non-probability technique is used in selecting the sample. Respondents had to meet two conditions before being qualified as valid respondents. Those conditions were that they had to be currently employed in one of the top 5 pharmaceutical companies in Egypt and actively working in the capacity of middle level management. We obtained a sample size of 300 to represent the targeted population. There are currently approximately 12,000 employees working in the middle level management departments of pharmaceutical companies in Egypt and specifically approximately 8,000 in the 5 largest local pharmaceutical companies. The research instrument used is a self-administered questionnaire which required respondents to take the responsibility to read and answer the questions. The questionnaires were distributed directly to the employees and it took around $10-15$ minutes for each respondent to complete it. The design of the questionnaire was separated into 3 sections, namely Sections A, B, and C respectively. Section A collected the respondents' demographic data which consists of elements such as gender, age, education level, position in the company and working experience. Section B consisted of three independent variables which are to determine the main effects of workforce diversity towards employees' performance. Each variable consisted of 5 to 9 questions to be answered by respondents. Section $\mathrm{C}$ consisted of 10 questions that asked about employee's performance. The total number of questions was 31 questions.

\subsection{Pilot Test}

After designing the questionnaire, reliability analysis was done to ensure measurements are reliable for our study. 20 sets of questionnaires have been distributed. Respondents were asked to comment and suggest changes to the questionnaire. Most of the feedbacks directed to the comprehensibility of items; therefore we modified some of the items to improve clarity. Reliability of the questionnaire was tested as well using reliability test in of Statistical Package for Social Science (SPSS) software. The result of pilot test is shown below.

Insert Table 1 here

Insert Table 2 here

Insert Table 3 here

Table 3 shows nine items that were used to measure the effect of gender in an organization towards employee's performance. Respondents were required to measure all items by rating on the five-point Likert's Scale with the range from strongly disagree (1) to strongly agree (5)

Insert Table 4 here 
Table 4 shows five items that were used to measure the effect of age in an organization towards employee's performance.

Insert Table 5 here

Table 5 shows seven items that were used to measure the effect of education background in an organization towards employee's performance.

Insert Table 6 here

Table 6 shows ten items that were used to measure the effect of education background in an organization towards employee's performance.

\section{Results}

Multiple Regression analysis was used to test the relationship between the independent variables and dependent variable. It was also used because it allowed examining which independent variables have the most significant influence on the dependent variable. Pearson's correlation coefficient analysis was used to better understand whether there is a positive relationship, negative relationship, or no correlation between dependent variable and independent variables. By using this analysis, the strength of relationships between variables was able to be analyzed and supported the reliability of the aforementioned 31 questions to be both reliable and valid.

In the 31 item questionnaire administered to the respondents after successfully passing the pilot study analyses, each respondent was asked four questions regarding their demographic profile, including gender, age, education level, working experience (in years), and position level in the organization. Frequency analysis of the demographic results showed that there are $50.3 \%$ of female respondents and $49.7 \%$ of male respondents. Most of the respondents are from degree holder which covers $59 \%$ of the total respondents. There are $18.7 \%$ master holders, $13.0 \%$ diploma holders, $8 \%$ of none degree holders and $1.3 \%$ of $\mathrm{PhD}$ holders. The position level includes $57 \%$ of executive, $27 \%$ entry level, $9.3 \%$ senior executive, $3.7 \%$ manager and $3.0 \%$ of senior manager. The majority respondents consist of $30-39$ years old which is $73.3 \%$ from the overall 300 respondents. There are $15 \%$ of $20-29$ years old, $10 \%$ of $40-49$ years old and $1.7 \%$ of 50 years old and above. Most of the respondent has 6-10 years working experience in this industry which is $50 \%$ of 300 respondents. There are $32.3 \%$ respondents has $2-5$ years working experience, $12.3 \%$ respondents has $10-15$ years working experience and 5.3\% respondents has more than 15 years working experience.

Insert Table 7 here

Table 7 shows an almost balanced percentage of respondents, whereby female (50.3\%), while male (49.7\%). In other words, from the 300 respondents, 149 of them are male while the remaining 151 are female.

Insert Table 8 here

Table 8 shows age group of the respondents. The majority of the respondents falls under the age group category of $30-39$ years old (accounted for $73.3 \%$ or 220 respondents), followed by the age group of $20-29$ years old (15\%or45 respondents), $40-49$ years old ( $10 \%$ or 30 respondents), and 50 years old and above (1.7\% or 5 respondents).

\section{Insert Table 9 here}

Table 9 shows the education level of the respondents. The majority of the respondents degree holders $(59 \%$ or 177 respondents), followed by masters (19\% or 56 respondents), diploma (13\% or 39 respondents), none (8\% or 24 respondents), and $\mathrm{PhD}$ ( $1 \%$ or 4 respondents). Most respondents are degree holders, because there a lot degree holders in the Egyptian labor market.

\section{Insert Table 10 here}

Table 10 shows that the highest proportion of respondents with $6-10$ years of working experience (50\% or 150 respondents), followed by $2-5$ years (32.3\% or 97 respondents), $10-15$ years ( $12.3 \%$ or 37 respondents), and more than 15 years $(5.3 \%$ or 16 respondents $)$

\section{Insert Table 11 here}

Table 11 shows that the majority of the respondents are executive level ( $57 \%$ or 171 respondents), followed by entry level ( $27 \%$ or 81 respondents), senior executive ( $9 \%$ or 28 respondents), manager ( $4 \%$ or 11 respondents), and (3\% or 9 respondents).

Reliability test and Cronbach's alpha were applied to observe the 31 items which used to measure the internal consistencies of the four constructs in the questionnaire. The alpha coefficient of gender ( 9 items) is 0.827 , age ( 5 items) is 0.738 , education background ( 7 items) is 0.800 , and employee performance ( 10 items) is 0.729 . According 
to Sekaran (2003), all constructs are found to have the internal consistency reliability if the result passed the minimum accepted level of 0.6 . The computed correlation between employee performance and gender is 0.333 , employee performance and age is -0.007 , and both employee performance and education background are 0.190 . All the constructs are statistically significant at the 0.01 level except the correlation for employee performance and age which has a negative correlation at -0.007 . Hence, the results proved that gender, and education background has a significant positive relationship with employee performance.

Furthermore, $56 \%$ of the respondents disagreed that he/she has been discriminated by employer while hiring and recruitment process, while $35 \%$ of them neither agreed nor disagreed with that statement. $77.7 \%$ of the respondents agreed that they feel the organization does a good job of attracting and hiring women, while $19.3 \%$ of them neither agreed nor disagreed with that statement. $61 \%$ of the respondents agreed that fair treatment is given to all employees whether they are male or female, while $28 \%$ of them neither agreed nor disagreed with that statement. $64.3 \%$ of the respondents agreed and $30.3 \%$ of them neither agreed nor disagreed that opportunities for growth and advancement exist for women in our organization.

There is a same percentage for the question for career development that includes women is encouraged within our organization which is $64.3 \%$ respondent agrees and $30.3 \%$ of them neither agreed nor disagreed. $77.7 \%$ of respondents agreed that the organization's training and development programs are developed to meet the criteria of the male and female genders and $19.3 \%$ of them neither agreed nor disagreed. $89.7 \%$ of respondents agreed that women are involved in the organization's decision making as much as men, while $9.7 \%$ of them neither agreed nor disagreed. $69.7 \%$ of respondents agreed that the performance criteria for success are expected to be higher for man than for women, while there is same percentage for strongly agreed and neither agreed nor disagreed which is $12.3 \% .77 .7 \%$ of the respondents agreed that they are think positive about gender diversity in this workplace, while $19.3 \%$ of them neither agreed nor disagreed with this statement. $44.7 \%$ of the respondents disagreed that the organization provides them with equal opportunities for training and career development, while $33.7 \%$ of them neither agreed nor disagreed with that statement. $42.7 \%$ of the respondents neither agreed nor disagreed that their team leaders include all members at different ages in problem solving and decision making, while $36 \%$ of them agreed. Both questions which are "the age differences in work group might cause conflict" and "at work, I experience lack of bonding with people of different age group" have the same result, which are $38.3 \%$ of the respondents disagreed and $29 \%$ of them neither agreed nor disagreed with the statement. $59.3 \%$ of the respondents agreed and $33.7 \%$ of them neither agreed nor disagreed that the organization does a good job of attracting and hiring minorities. $69.7 \%$ of the respondents agreed and $12.3 \%$ of them neither agreed nor disagreed and strongly agreed that they have opportunities for growth and advancement exist for minorities in their organization.

There were 2 questions which are "the organization concerns about the employees' customs, cultures and values and "The team leader includes all members in problem solving and decision making" have the result $55.7 \%$ agreed and $28 \%$ neither agreed nor disagreed on the statements. $47 \%$ of the respondents disagreed and $33.7 \%$ neither agreed nor disagreed that the recruitment plan of the organization is based on the education background of the employees and also get the same result for the question "the difference in education background does not encourage conflict". $44.7 \%$ of the respondents agreed and $37.3 \%$ of them neither agreed nor disagreed that the organization provides paid study leave to employees who further their education. $34.3 \%$ of the respondents agreed and $48 \%$ of them neither agreed nor disagreed that "Opportunities for growth and advancement exist for employees who have lower qualification in education", while $13.3 \%$ of them disagreed with that statement. $38.3 \%$ of the respondent disagreed and $29 \%$ of them neither agreed nor disagreed that at work, they experience lack of confidence due to their education background, while $24 \%$ of them agreed with that statement. $47.7 \%$ of the respondents neither agreed nor disagreed and $40 \%$ of them agreed that their team leader includes all members at different education level in problem solving and decision making. $47 \%$ of the respondents disagreed that their organization gives equal treatment when it comes to the diversity of education background, while $33.7 \%$ of them neither agreed nor disagreed with that statement. $73.7 \%$ of the respondents agreed that they enjoy their tasks and the divisions work approach while $18 \%$ neither agreed nor disagreed with that statement. $74 \%$ of the respondents agreed and $22.7 \%$ of them neither agreed nor disagreed that they are committed to the mission and direction of their organization. There was less than half of the respondents $(23.3 \%)$ neither agreed nor disagreed and $64.3 \%$ of them agreed that they were motivated to complete the task that is assigned to them. $63.3 \%$ of the respondents agreed and $19 \%$ of them neither agreed nor disagreed that they co-operate well with their colleagues. More than half of the respondents $(61 \%)$ agreed that opposite gender can perform well and they enjoy working with them, while $24.7 \%$ of them neither agreed nor disagreed with that statement. $68.3 \%$ of the respondents agreed and $22.3 \%$ of them strongly agreed that their performance levels affects their salary levels. There is slightly high percentage for the respondents disagree and strongly disagreed to satisfy 
with their current salary level which is $82.3 \%$ and $14.7 \%$ respectively. Finally, there was $83 \%$ of the respondents agreed and $8.7 \%$ of them neither agreed nor disagreed that they are given the chance to try their own method of doing the job.

According to the Model Summary, the value of correlation coefficient $(\mathrm{R})$ of three independent variables (gender, age, and education background) with the dependent variable (employee performance) is 0.455 . Therefore, there is positive and moderate correlation between the three independent variable and dependent variable. Besides that, Model Summary also indicates the coefficient of determination ( $\mathrm{R}$ square) which can help in explaining variance. The $\mathrm{R}$ square figure of the three independent variables is 0.207 . These also mean that independent variables (gender, age, and education background) can explain $20.7 \%$ of the variation in dependent variable (employee performance). However, it is still leaves $79.3 \%(100 \%-20.7 \%)$ unexplained in this research. In other words, there are other additional variables that are important in explaining employee performance that have not been considered in this research.

\section{Insert Table 12 here \\ Insert Table 13 here}

Tables 12 and 13 show that the gender group is the first and most significant independent variable in this research since its t-value is 6.780 and $\mathrm{p}$-value is 0.000 , which is lower than alpha value 0.01 . This also shows that gender group is significant to predict perceived employee performance. Besides that, gender group is the predictor variable that contribute the highest to the variation of the perceived employee performance because Beta value (under standardized coefficients) for this predictor variable is the largest (0.360) if compare to other predictor variables (age and education background). Besides, education background group is second most significant independent variable where it carries out the t-value 4.307 and the p-value 0.000 , which is lower than the alpha value 0.01 . This shows that education background group is significant to predict perceived employee performance. In addition, education background group contribute the second highest to the variation of the perceived employee performance because Beta value (under standardized coefficients) for this predictor variable is the second largest (0.347). The third most significant independent variable is age group where it carries out the t-value -4.436 and the p-value 0.000 , which is lower than the alpha value 0.01 . This shows that age group is significant to predict perceived employee performance. In addition, age group contributes Beta value (under standardized coefficients) for this predictor variable is $(-0.315)$. The result indicates that the gender group, education background group, and age group have a significant relationship with the employee performance.

\section{Discussion}

In the construct of gender, the statement of "women are involved in the organization's decision making as much as man" is the highest mean which is 3.91 , followed by "the performance criteria for success are expected to be higher for man than for women" which is 3.89. The statement of "the organization does a great job in attracting and hiring women", "the organization's training and development program is developed to meet the criteria/requirement of the male and female" and "I am positive about the gender diversity in this workplace" has the third highest mean at 3.80.Fourth highest mean is "fair treatment is given to all employees, whether they are male or female" which is 3.73 . Fifth is the item "opportunities for growth and advancement exist for women in our organization" and "a career development that includes women is encouraged within our organization" which is 3.67. The lowest mean 2.39 is the item "the employees have not been discriminated by employer while hiring and recruitment process on the gender basis". The standard deviation of gender, for the item "the performance criteria for success are expected to be higher for men and women" is the highest at 0.680 ". Second highest is "fair treatment is given to all employees, whether they are male or female" at 0.658 . Third highest is "the employees have not been discriminated by employer while hiring and recruitment process on the gender basis" at 0.648 . The fourth highest is the item "opportunities for growth and advancement exist for women in our organization" and "a career development that includes women is encouraged within our organization" with standard deviation 0.586 . Fifth highest are the item "the organization does a great job in attracting and hiring women", "the organization's training and development program is developed to meet the criteria/requirement of the male and female", "I am positive about gender diversity in this workplace" with the same standard deviation 0.472. The lowest standard deviation is "women are involved in the organization's decision making as much as man" with standard deviation 0.309.

In the construct of age, the statement of "I am positive about age diversity in this workplace" is the highest mean 3.54. Second highest mean is the item "my team leaders include all members at different age in problem solving and decision making" at 3.28. Third highest mean is "the age differences in work group might cause conflict" and "at work, I experience lack of bonding with people of different age group" at 2.84. The lowest mean is the item "this 
organization provides me equal opportunities for training and career development" at 2.64. The standard deviation of age, for the item "the age differences in workgroup might cause conflict" and "at work, I experience lack of bonding with people of different age group" is the highest at 0.974 . Next is the item "this organization provides me equal opportunities for training and career development" at standard deviation 0.816 . Third is the item "my team leaders include all members at different age in problem solving and decision making" at 0.793 . Lastly, the item "I am positive about age diversity in this workplace" with the lowest standard deviation 0.574 .

In the construct of education background, the highest mean 3.33is the item "the team leader includes all members at different education level in problem solving and decision making". Second highest mean is 3.27 for the item "the organization provides paid study leave to employees who further their education". Third highest mean is 3.12 for the item "opportunities for growth and advancement exist for employees who have lower qualification in education". Fourth is the item "at work I experience lack of confidence due to my education background" at mean of 2.84. The lowest the mean is 2.59 for the item "the recruitment plan of the organization is based on the education background of employees", "the differences in education background do not encouraged conflict" and "the organization gives equal treatment when it comes to the diversity of education background". The standard deviation of education background for the item "at work I experience lack of confidence due to my education background" is the highest which is at 0.974 . Second highest is the item "the organization provides paid study leave to employees who further their education" at 0.840 . Third highest is 0.798 for the item "opportunities for growth and advancement exist for employees who have lower qualification in education". There are four items at fourth highest standard deviation 0.794 which is "the recruitment plan of the organization is based on the education background of employees", the "differences in education background do not encouraged conflict" and "the organization gives equal treatment when it comes to the diversity of education background". The lowest standard deviation is 0.684 which is the item "the team leader includes all members at different education level in problem solving and decision making".

In the construct of employee performance, there are three items with the highest mean; 4.13 which are "my performance level affects my salary level", "by learning more skills through courses/training, I can improve my task performance" and "good employee performance is important for the future growth of my organization". The second highest mean is the item "I am motivated to complete the task that is assigned to me" at the mean of 3.89. The fourth highest 3.87 is the item "I enjoy my task and division's work approach" and "opposite gender can perform well and I enjoy working with them". The fifth highest mean is 3.80 for the item "I am committed to the mission and direction of my organization". The lowest mean with 1.88 is the item "I am satisfied with my current salary level". The standard deviation for employee performance for the item "opposite gender can perform well and I enjoy working with them" is the highest at 0.635 . For the secondhigheststandarddeviation 0.606 is the item "I co-operate well with my colleagues". The third highest is 0.588 for the item "I am motivated to complete the task that is assigned to me". Fourth highest standard deviation is at 0.548 for 3 items "my performance level affects my salary level", "by learning more skills through courses/training, I can improve my task performance" and "good employee performance is important for the future growth of my organization". The fifth highest standard deviation is 0.508 for the item "I enjoy my task and division's work approach". On the other hand, the sixth highest standard deviation is 0.479 for the item "I am committed to the mission and direction of my organization". The seventh highest standard deviation is 0.425 for the item "I am given the chance to try my own method of doing job". Last but not least, the lowest standard deviation is 0.404 for the item "I am satisfied with my current salary level". The standard deviation for employee performance for the item "opposite gender can perform well and I enjoy working with them" is the highest at 0.635. For the second highest standard deviation 0.606 is the item "I cooperate well with my colleagues". The third highest is 0.588 for the item "I am motivated to complete the task that is assigned to me". Fourth highest standard deviation is at 0.548 for 3 items "my performance level affects my salary level", "by learning more skills through courses/training, I can improve my task performance" and "good employee performance is important for the future growth of my organization". The fifth highest standard deviation is 0.508 for the item "I enjoy my task and division's work approach". On the other hand, the sixth highest standard deviation is 0.479 for the item "I am committed to the mission and direction of my organization". The seventh highest standard deviation is 0.425 for the item "I am given the chance to try my own method of doing job". Last but not least, the lowest standard deviation is 0.404 for the item "I am satisfied with my current salary level".

Based on the results of multiple regression analysis, $\mathrm{R}^{2}=0.207$ means that $20.7 \%$ of the variation employee performance is explained by gender, age, and education background. Besides that, the F-value of 19.208 is significant at the 0.01 level means that this model is a good descriptor of the relation between the employee performance and predictor variables (gender, age, and education background). In other words, the independent 
variables (gender, age, and education background) are significantly explaining the variance in employee performance.

\section{Insert Table 14 here}

H1: There is significant relationship between gender group and employee performance

Based on the results, there is a significant positive and small but definite relationship between gender group and employee performance which carries correlation coefficient value of 0.333 and p-value of 0.000 which is significant at the alpha value 0.01 . The findings showed that gender group and employee performance is positively linked. Based on the information provided in the research the overall feeling is that, for the most part, gender was not an area of concern. All divisions of the company must meet annual targets for the representation of majority and minority males and females in each employee grade level (Kochan et al., 2002). In order to enforce the employee performance, performance appraisals employees included measures employees' ability to achieve the targets. According to Kochan et al., (2002), the performance appraisals were used for making promotion and compensation related decisions. Training practices included intensive diversity training. Trainers used behavioral modeling techniques to help develop managerial capabilities for interacting with subordinates and colleagues irrespective of demographic differences. Thus the training efforts focused more on skill-building than on building awareness or modifying attitudes.

$\mathrm{H} 2$ : There is no significant relationship between age group and employee performance

Based on the results, there is no significant and slight, almost negligible relationship between age group and employee performance which carries correlation coefficient value of- 0.007 and $p$-value of 0.908 which is no significant at the alpha value 0.01 . Age is also regularly viewed as one dimension of social category diversity (Jehn et al., 1999; Simons et al., 1999; and Pelled et al., 1999). However, we find no influence of age diversity on performance, which agrees to the findings of the empirical studies reviewed in Williams and O'Reilly (1998) and Jackson et al., (2003). A possible reason why we find no effect of age diversity is the less pronounced numerical distinctiveness between younger and older managers as compared to the numerical distinctiveness between female and male managers. Thus, age is probably less salient than gender and consequently age diversity has a less pronounced influence (Pelled, 1993). According to Baer et al., (2007), a further increase in group heterogeneity with the extreme case of an equal number of team members in each diversity category mitigates this effect. Furthermore, in the sample, age might also be a proxy for experience or status rather than for social category. Young and old employees are likely to have varied status seeking tendencies. Overbeck et al., (2005) and Groysberg et al., (2007) show that teams with too many individuals seeking for high status do not collaborate well since their attempt to gain status disrupts information sharing. Furthermore, there is no negative effect when age diversity is very high, and the decision-making process does not seem to benefit from increased diversity, as indicated by Wegge et al., (2008).

H3: There is significant relationship between education background group and employee performance

Based on the results, there is significant positive and slight, almost negligible relationship between education background group and employee performance which carries correlation coefficient value of 0.190and p-value of 0.001 which is significant at the alpha value 0.01 . Different education types, or a more balance in the education types a firm possesses would increase the likelihood of having an innovation. There is a bias in the education diversity measure, since it measures diversity within the highly educated group, meaning the employees with a bachelor degree or higher. All employees with a degree below bachelor are put in a single category. According to the Ostergaard (2002), as a result a higher entropy value can be explained by having a larger share of employees with a higher education and multiple types of higher educated people. Having a higher educated employee alone would be positive for innovation performance, having more different types would increase the likelihood (Ostergaard, 2002). Firms with a higher share of employees with a higher education and diversity in the types of educations have a higher likelihood of innovating. Although education is essential to human capital, on job training, heath care, experience and migration also have great effect on the actual human capital. Growth-oriented strategies moderated the effects of group diversity in level of education on composite bonuses; this type of diversity was more beneficial in department with a strong focus on growth oriented-strategies (Bezrukova, 2004). An organization may make an effort to compensate for education or skill deficiencies of group members by offering specialized training that brings employees up to the required standards (Moskos and Butler, 1996).

\section{Conclusion}

The results clearly indicate that it is important for any organization to implement diversity management. The results specifically indicate that high employee performance relates positively with variables such as gender and education 
background. Therefore, business organizations should start realizing the need to tackle such demographic categories in order to stay ahead of its competitors. Organizations that view diversity as part of their key strategy rather than a business expense will benefit far greater than the organization that does not, and will reap the benefit of cost reduction in attrition and increased revenues (Brown, 2008; Stalinski, 2004). Jayne \& Dipboye (2004) pointed out that the increasing attention given to diversity management reflects the inevitable consequence of a global economy and demographic changes. Therefore by achieving a diverse workforce, it can effectively manage to yield huge benefits for an organization. Furthermore, the results indicate that workforce diversity lead to synergistic performance when team members are able to understand and appreciate each other, and capitalize on one another's experiences, knowledge and perspectives. Furthermore, through effective communication, members would be able to evaluate problems and situations from various viewpoints, determine underlying cultural assumptions and create a common social reality, ascertain and explain culturally synergistic alternative solutions appropriately, and establish agreed-upon norms for interaction (Choy, 2007; Adler, 1980; Maznevski, 1995). Diversifying workers from different education background creates opportunities for greater innovation and more creative solutions to problems (Richard, 2000; Richard, 2003; Watson, 1993). Consequently, when the management is diversified and work on increasing diversity, this will be the key to assuring that organizations will be able to fully benefit from bringing underrepresented groups into organizations.

Furthermore, workforce diversity is closely related with Human Resource Management to attract and recruit the most talented people from a large pool of diverse workforce. Such a diversity-driven approach towards recruiting a range of qualified candidates is needed because of the Egypt's diverse population of age and gender (Soltani, 2010). According to Soltani, diversified human resources contribute to determining and realizing strategic objectives of the organization, and a systemized approach for making a linkage between organization excellence and effective people management is critical to organizational continuity (Berger and Berger 2003). The optimum outcome of this study is to benefit the pharmaceutical industry in Egypt by getting along with the top management and workers from different backgrounds that would find the information in this study useful in accessing the value of workforce diversity in their respective organizations. Competition for the best talent requires organizations to reach out and embrace an increasingly diverse labor pool. Secondly, a global economy requires that organizations have a diverse workforce so that they can effectively deal with an increasingly diverse customer base. Thus, a diverse workforce can lead to an increased market share, whereas lack of diversity in the workforce can lead to a shrinking market share. Demographic diversity also unleashes creativity, innovation, and improved group problem solving, which in turn enhances the competitiveness and the level of performance in an organization. In a multicultural society, attempting to increase workforce diversity is simply the right and ethical thing to do as corporate citizens, regardless of the economic implications.

\section{References}

Aamodt, M. \& Flink, W. (2001). Relationship between education level and cadet performance in a police academy. Applied H.R.M. Research, 6 (1), 75-76.

Abbas, Q. \& Hameed, A. (2010). Gender discrimination and its effect on employee performance or productivity. Unpublished manuscript, Paper presented at the $3^{\text {rd }}$ Annual EuroMed Conference of the EuroMed Academy of Business, University of Nicosia, Cyprus.

Amason, A. (1996). Distinguishing the effects of functional and dysfunctional conflict on strategic decision making: Resolving a paradox for top management teams. Academy of Management Journal, 39 (1), 123-148. http://dx.doi.org/10.2307/256633

Baer, M., Niessen, A., \& Ruenzi, S. (2007). The impact of work group diversity on performance: Large sample evidence from the mutual fund industry. Unpublished manuscript, Centre for Financial Research, University of Cologne. [Online]: Available: http://www.cfr-cologne.de/download/workingpaper/cfr-07-16.pdf (December, 4, 2012)

Bantel, K., \& Jackson, S. (1989). Top management and innovations in banking: Does the composition of the top team make a difference? Strategic Management Journal, 10, 107-124. http://dx.doi.org/10.1002/smj.4250100709

Benschop, Y. (2001). Pride, prejudice and performance: Relations between HRM, diversity and performance. International Journal of Human Resource Management, 12 (7), 1166-1181.

http://dx.doi.org/10.1080/09585190110068377

Bezrukova, K. (2004). A field study of group diversity, group context, and performance. Journal of Organizational Behavior, 25 (6), 703-729. http://dx.doi.org/10.1002/job.266 
Brown, S. (2008). Diversity in the workplace: A study of gender, race, age, and salary level. MI: ProQuest Information and Learning. [Online] Available: http://books.google.ca/books?id=E7koeCfkOoIC\&printsec=frontcover\&source=gbs_ge_summary_r\&cad $=0 \# v=$ onep age\&q\&f=false (December 4, 2012)

Burns, A., \& Bush, R. (2006). Marketing research. New Jersey: Pearson Education Press.

Carpenter, M., \& Fredrickson, J. (2001).Top management teams, global strategic posture, and the moderating role of uncertainty. Academy of Management Journal, 44 (3), 533-545. http://dx.doi.org/10.2307/3069368

Chan, A. (2009). The challenges of human resource management. India: Excel Books.

Childs, J., (2005). Managing workforce diversity at IBM: A global HR topic that has arrived. Human Resource Management, 44 (1), 73-77. http://dx.doi.org/10.1002/hrm.20042

Choy, W. (2007). Globalization and workforce diversity: HRM implications for multinational corporations in Singapore. Singapore Management Review, 29 (2), 1-19.

Clarke, K. (2004). Case study: Implementing a revenue management system at Malaysia Airlines. Journal of Revenue \& Pricing Management, 3 (1), 41-48. http://dx.doi.org/10.1057/palgrave.rpm.5170092

Cohen, S., \& Bailey, D. (2001). What makes teams work: Group effectiveness research from the shop floor to the executive suite. Journal of Management, 23 (3), 239-290. http://dx.doi.org/10.1177/014920639702300303

Cooper, D., \& Schindler, P. (2006). Marketing Research. New York: McGraw-Hill.

Cox, T. (1994). Cultural diversity in organizations: Theory, research, and practice. San Francisco: Berrett Koehler.

Creswell, J. (2009). Research design: Qualitative, quantitative, and mixed methods approaches. London: SAGE Publications.

Dahlin, K., Weingart, L., \& Hinds, P., (2005). Team diversity and information use. The Academy of Management Journal, 48 (6), 1107-1123. http://dx.doi.org/10.5465/AMJ.2005.19573112

Dahm, M. (2003). The development of a needs analysis instrument for cultural diversity training: WDQ-II. Unpublished manuscript, University of Houston, Texas.

Daniel C. (2009). The effects of higher education policy on the location decision of individuals: Evidence from Florida's Bright Futures Scholarship program. Regional Science and Urban Economics, 39, 553- 562. http://dx.doi.org/10.1016/j.regsciurbeco.2009.04.002

De Dreu, C., \& Van de Vliert, E. (1997). Using Conflict in Organizations. London: Sage Publications.

De Dreu, C., \& Weingart R. (2003). Task versus relationship conflict, team performance, and team member satisfaction: A meta-analysis. Journal of Applied Psychology , 88 (4), 741-749. http://dx.doi.org/ 10.1037/0021-9010.88.4.741

Dee, T. (2004). Are there civic returns to education? Journal of Public Economics, 88 (9-10), 1697-1720. http://dx.doi.org/10.1016/j.jpubeco.2003.11.002

DiPaola, M., \& Hoy, W. (2001). Formalization, conflict, and change: Constructive and destructive consequences in schools. International Journal of Education Management, $15 \quad$ (5), 238-244. http://dx.doi.org/10.1108/EUM000000005512

Dreachslin, J. (1996). Diversity leadership. Chicago: Health Administration Press.

Dreachslin, J., Hunt, P., \& Sprainer, E. (2000). Workforce diversity: implications for the effectiveness of health care delivery teams. Social Science \& Medicine, 50 (10), 1403-1414. http://dx.doi.org/10.1016/S0277-9536(99)00396-2

Ely, R., \& Thomas, D. (2001). Cultural diversity at work: The effect of diversity perspectives on work group processes and outcomes. Administrative Science Quarterly, 46 (2), 229-273. http://dx.doi.org/10.2307/2667087

Erasmus. L. (2007). The management of workforce diversity and the implications for leadership at financial asset services. Unpublished manuscript, University of Johannesburg, South Africa. Available: https://ujdigispace.uj.ac.za/handle/10210/356 (December 4, 2012)

Francisco, M., Munduate, L., Dorado, M., Inés, M., \& Guerra, M. (2005). Types of intragroup conflict and affective reactions. Journal of Managerial Psychology, 20 (3/4), 219-230. http://dx.doi.org/10.1108/02683940510589019 
Friedman, R., Tidd, S., Currall, S., \& Tsai, J. (2000). What goes around comes around: The impact of personal conflict styles on work conflict and stress. International Journal of Conflict Management, 11 (1), 32-55. http://dx.doi.org/10.1108/eb022834

Gilbert, J., \& Ivancevich, J. (2000). Valuing diversity: A tale of two organizations. Academy of Management Executive, 14 (1), 93-105. http://dx.doi.org/10.5465/AME.2000.2909842

Glaeser, E., Scheinkman, J., \& Shleifer, A. (1995). Economic growth in a cross- section of cities. Journal of Monetary Economics, 36 (1), 117-143. http://dx.doi.org/10.1016/0304-3932(95)01206-2

Gobler P. (2002). Human Resource Management in South Africa. London: Thompson Learning.

Gwendolyn, M. (2002). Meeting the leadership challenge of a diverse and pluralistic workplace: Implications of self-efficacy for diversity training. Journal of Leadership\& Organizational Studies, 8 (4), 1-16. http://dx.doi.org/10.1177/107179190200800401

Hair, J., Money, A., Samouel, P., \& Babin, B. (2003). Essential of Business Research Methods. New York: John Wiley and Sons.

Hair, J., Money, A., Samouel, P., \& Page, M. (2007). Research Methods for Business. West Sussex: John Wiley \& Sons.

Hambrick, D., \& Mason, P. (1984). Upper echelons: The organization as a reflection of its top managers. Academy of Management Review, 9 (2), 193- 206. http://dx.doi.org/10.5465/AMR.1984.4277628

Hargie, O., \& Tourish, D. (2009). Auditing organizational communication: a handbook of research, theory and practice. East Sussex: Routledge.

Harrison, D., \& Klein, K. (2007). What's the difference? Diversity constructs as separation, variety, or disparity in organizations. The Academy of Management Review, 32 (4), 1199-1228. http://dx.doi.org/10.5465/AMR.2007.26586096

Hasan, A., Muhammad, A., \& Imran, A. (2009). Linkage between employee's performance and relationship conflict in banking scenario. International Journal of Business Management, 4 (7), 19-25.

Hogg, M., \& Terry, D. (2000). Social identity and self-categorization processes in organizational contexts. Academy of Management Review, 25(1), 121-140. http://dx.doi.org/10.5465/AMR.2000.2791606

Holland, J. (1997). Making vocational choices: A theory of career. New Jersey: Prentice Hall.

Inmyxai, S. \& Takahashi Y. (2010). Performance comparison derived from human resources between male and female headed firms in the Lao MSMEs. International Review of Business Research Papers, 6 (2), 12-38.

Jackson, S., \& Joshi, A. (2004). Diversity in social context: A multi-attribute, multilevel analysis of team diversity and sales performance. Journal of Organizational Behavior, 25, 675-702. http://dx.doi.org/10.1002/job.265

Jackson, S., May, K., \& Whitney, K. (2005). Understanding the dynamics of diversity in decision-making teams. In R. A. Guzzo, E. Salas, \& Associates (Eds.). Team effectiveness and decision making in organizations (pp. 204-261). San Francisco: Jossey-Bass.

Jayne, M., \& Dipboye, R. (2004). Leveraging diversity to improve business performance research findings and recommendations for organizations. Human Resource Management, 43 (4), 409-424. http://dx.doi.org/10.1002/hrm.20033

Jehn, K. (1994). Enhancing effectiveness: An investigation of advantages and disadvantages of value-based intragroup conflict. International Journal of Conflict Management, 5 (3), 223-38. http://dx.doi.org/10.1108/eb022744

Jehn, K. (1995). A multimethod examination of the benefits and detriments of intragroup conflict. Administrative Science Quarterly, 40, 256-82. http://dx.doi.org/10.2307/2393638

Jehn, K., \& Bezrukova, K. (2004). A field study of group diversity: Workgroup context and performance. Journal of Organizational Behavior, 25 (6), 703-729. http://dx.doi.org/10.1002/job.257

Jehn, K., Chatwick, C., \& Thatcher, S. (1997). To agree or not to agree: The effects of value congruence, individual demographic dissimilarity, and conflict on workgroup outcomes. International Journal of Conflict Management, 8 (4), 287-305. http://dx.doi.org/10.1108/eb022799 
Jehn, K. A., Northcraft, G. B., \& Neale, M. A. (1999). Why differences make a difference: a field study in diversity, conflict, and performance in workgroups. Administrative Science Quarterly, 44, 741-763. http://dx.doi.org/10.2307/2667054

Jonathan, S., David, I., \& Aparna, J. (2004). Do birds of a feather shop together? The effects on performance of employees? similarity with one another and with customers. Journal of Organizational Behavior, 25, 731-754. http://dx.doi.org/10.1002/job.267

Joshi, A., \& Jackson, S. (2003). International Handbook of Organizational Teamwork and Cooperative Working. New York: John Wiley and Sons.

Hair, J., Bush, R., \& Ortinau, T. (2008). Marketing Research: In a Digital Information Environment. New York: McGraw-Hill/Irwin.

Knight, D., Pearce, C., Smith, K., Olian, J., Sims, H., \& Smith, K. (1999).Top management team diversity, group process, and strategic consensus. Strategic Management Journal, 20 (5), 445-465. http://dx.doi.org/10.2307/3094164

Kochan, T., Bezrukova, K., Ely, R., Jackson, S., Joshi, A., Jehn, K., Leonard, J., Levine, D., \& Thomas, D. (2003). The effects of diversity on business performance: Report of the diversity research network. Human Resource Management, 42 (1), 3-21. http://dx.doi.org/10.1002/hrm.10061

Kochan, T., Bezrukova, K., \& Ely, R., Jackson, S., Joshi, A., Jehn, K. (2002). The Effects of Diversity on Business Performance. Alexandria, VA: Diversity Research Network.

Kundu, S. (2003). Workforce diversity status: A study of employees' reactions. Industrial Management \& Data Systems, 103 (4), 215-226. http://dx.doi.org/10.1108/02635570310470610

Kunze, F., Boehm, S., \& Bruch H. (2011). Age diversity, age discrimination, and performance consequences - A cross organizational study. Journal of Organizational Behavior, 32, 264-290. http://dx.doi.org/10.1002/job.698

Leonard, J., \& Levine, D. (2003). Diversity, discrimination and performance. Institute For Research on Labor and Employment, California: UC Berkeley Press. [Online] Available: http://ideas.repec.org/p/cdl/indrel/qt2p3880ms.html (December 5, 2012)

Lochner, L. \& Moretti, E. (2004). The effects of education on crime: Evidence from prison inmates, arrests, and self-reports. American Economic Review, 94 (1), 155-189. http://dx.doi.org/10.1257/000282804322970751

West, M., Tjosvold, D., \& Smith, K. (2003). Managing workforce diversity to enhance cooperation in an organization. New York: John Wiley \& Sons.

Mack, R. (1965). The components of social conflict. Social Problems, 22 (4), 388-397. http://dx.doi.org/10.2307/798839

Maznevski, M. (1994). Performance in decision-making groups with diverse members. Human Relations, 47 (5), 531-552. http://dx.doi.org/10.1177/001872679404700504

Milliken, F., \& Martins, L. (1996). Searching for common threads: Understanding the multiple effects of diversity in organizational groups. Academy of Management Review, 21 (2), 402-433. http://dx.doi.org/10.5465/AMR.1996.9605060217

Moretti, E. (2004). Estimating the social return to higher education: Evidence from longitudinal and repeated cross-sectional data. Journal of Econometrics, 121, 175-212. http://dx.doi.org/10.1016/j.jeconom.2003.10.015

Moskos, C. (1996). Black leadership and racial integration the army way. New York: Basic Book.

Nemetz, P., \& Christensen, S. (1996). The challenge of cultural diversity: Harnessing a diversity of views to understand multiculturalism. Academy of Management Review, 21, 434-462. http://dx.doi.org/10.5465/AMR.1996.9605060218

Ostergaard, C., \& Timmermans, B., \& Kristinsson, K.(2011). Does a different view create something new? The effect of employee diversity on innovation. Research Policy, 40 (3), 500-509. http://dx.doi.org/10.1016/j.respol.2010.11.004

Owoyemi, O., Elegbede, T., \& Gbajumo-Sheriff, M. (2011). Age diversity and the future of workforce in Nigeria. European Journal of Economics, Finance \& Administrative Sciences, 30, 65-75. 
Passos, M., \& Caetano, A. (2005). Exploring the effects of intragroup conflict and past performance feedback on team effectiveness. Journal of Managerial Psychology, 20 (3/4), 231-244. http://dx.doi.org/10.1108/02683940510589028

Pelled, L., Eisenhardt, K., \& Xin, K. (1999). Exploring the black box: An analysis of work group diversity, conflict, and performance. Administrative Science Quarterly, 44 (1), 1-28. http://dx.doi.org/10.2307/2667029

Pitts, D., Hicklin, A., Hawes, D., \& Melton, E. (2010). What drives the implementation of diversity management programs? Evidence from public organizations. Journal of Public Administration Research \& Theory, 20 (4), 867-886. http://dx.doi.org/10.1093/jopart/mup044

Pondy, L. (1967). Organizational conflict: Concepts and models. Administrative Science Quarterly, 12 (2), 296-320. http://dx.doi.org/10.2307/2391553

Raatikainen, P. (2002). Contributions of multiculturalism to the competitive advantage of an organization. Singapore Management Review, 24 (1), 81-88.

Richard, O. (2000). Racial diversity, business strategy, and firm performance: A resource- based view. Academy of Management Journal, 43 (2), 164-177. http://dx.doi.org/10.2307/1556374

Robbins. (2009). The equal opportunities handbook: How to recognize diversity, encourage fairness and promote anti-discriminatory practice. In L. Roberson \& C. T. Kuluk (Eds.). Stereotype Threat at Work (pp. 136-154). London: Kogan Page.

Sekaran, U. (2003). Research methods for business: A skill building approach . New York: John Wiley \& Sons.

Shaw, M. (1993). Achieving equality of treatment and opportunity in the workplace. In R.Harrison (Ed). Human resource management: Issues and strategies (pp. 189-221). Wokingham: Addison-Wesley.

Simons, T., \& Peterson, R. (2000). Task conflict and relationship conflict in top management teams: The pivotal role of intragroup trust. Journal of Applied Psychology, 85 (1), 102-111. http://dx.doi.org/10.1037/0021-9010.85.1.102

Soltani, E. (2010). The overlooked variable in managing human resources of Iranian organizations: Workforce diversity - some evidence. International Journal of Human Resource Management, 21 (1), 84-108. http://dx.doi.org/10.1080/09585190903466871

Strauss, A., \& Corbin, J. (1994). Grounded theory methodology: An overview. In N. Denzin \& Y. Lincoln (Eds.). Handbook of qualitative research (pp. 273-285). Thousand Oaks, CA: Sage.

Timmermans, B., Ostergaard, C., \& Kristinsson, K. (2011). Does a different view create something new? The effect of employee diversity on innovation. Research Policy, 40 (3), 500-509. http://dx.doi.org/10.1016/j.respol.2010.11.004

Tracy R., \& Sappington, D. (1993). Choosing workers' qualifications: No experience necessary? International Economic Review, 34 (3), 479-502. http://dx.doi.org/10.2307/2527178

Van Esbroek, W., \& Van Engen. M. (2008). Management van diversiteit en Rechtvaardigheid: Op zoek naar een Beste benadering. Tijdschrift voor HRM, 63-90.

Van Knippenberg, D., De Dreu, C., \& Homan, A. (2004). Work group diversity and group performance: An integrative model and research agenda. Journal of Applied Psychology, 89 (6), 1008-1022. http://dx.doi.org/10.1037/0021-9010.89.6.1008

Wall, J., \& Callister, R. (1995). Conflict and its management. Journal of Management, 21 (3), 515-58. http://dx.doi.org/10.1177/014920639502100306

Wegge, J., Roth, C., Neubach, B., Schmidt, K., \& Kanfer, R. (2008). Age and gender diversity as determinants of performance and health in a public organization: The role of task complexity and group size. Journal of Applied Psychology, 93 (6), 1301-1313. http://dx.doi.org/10.1037/a0012680

Wentling R., \& Rivas, N. (2000). Current status of diversity initiatives in selected multinational corporations. Human Resource Development Quarterly, $11 \quad 35-60$. http://dx.doi.org/10.1002/1532-1096(200021)11:1<35::AID-HRDQ4>3.0.CO;2-\#

Wiersema, M., \& Bird, A. (2003). Organizational demography in Japanese firms: Group heterogeneity, individual dissimilarity, and top management team turnover. Academy of Management Journal, 36 (5), 996-1025. 
Williams, K., \& O’Reilly, C. (1998). Demography and diversity: A review of 40 years of research. In B. Staw, \& R. Sutton (Eds.). Research in Organizational Behavior, (pp. 77-140). Greenwich, CT: JAI Press

Zikmund, W., Babin, B., Carr, J., \& Griffin, M. (2010). Business Research Methods. New York: South-Western/Cengage Learning.

Zikmund, W. (2003). Business Research Methods. Ohio: Thomson.

Table 1. Reliability test results

\begin{tabular}{|l|l|l|l|}
\hline Number & Constructs & Coefficient Alpha & Number of item \\
\hline 1 & Gender & 0.807 & 9 \\
\hline 2 & Age & 0.790 & 5 \\
\hline 3 & Education Background & 0.843 & 7 \\
\hline 4 & Employee performance & 0.736 & 10 \\
\hline
\end{tabular}

Table 2. The origin of construct in the research

\begin{tabular}{|l|l|}
\hline Constructs & Adapted from \\
\hline Gender & Abbas \& Hameed (2010) \\
\hline Age & Abbas \& Hameed (2010) \\
\hline Education Background & Giles (2008) \\
\hline Employee performance & Giles (2008) \\
\hline
\end{tabular}

Table 3. Modified Operational Definition of construct for gender

\begin{tabular}{|l|l|}
\hline Q1 & $\begin{array}{l}\text { The employees have not been discriminated by employer while hiring and } \\
\text { recruitment process on the gender basis. }\end{array}$ \\
\hline Q2 & The organization does a good job of attracting and hiring women. \\
\hline Q3 & Fair treatment is given to all employees, whether they are male or female. \\
\hline Q4 & Opportunities for growth and advancement exist for women in our organization. \\
\hline Q5 & A career development that includes women is encouraged within our \\
\hline Q6 & $\begin{array}{l}\text { The organization's training and development program is developed to meet the } \\
\text { criteria/requirement of the male and female gender. }\end{array}$ \\
\hline Q7 & Women are involved in the organization's decision making as much as men. \\
\hline Q8 & $\begin{array}{l}\text { The performance criteria for success are expected to be higher for men than for } \\
\text { women. }\end{array}$ \\
\hline Q9 & I am positive about gender diversity in this workplace \\
\hline
\end{tabular}

Table 4. Modified Operational Definition of construct for age

\begin{tabular}{|l|l|}
\hline Q10 & This organization provides me with equal opportunities for training and career development. \\
\hline Q11 & My team leaders include all members at different ages in problem solving and decision making. \\
\hline Q12 & The age differences in work group do not cause conflict. \\
\hline Q13 & At work, I experience lack of bonding with people of different age group. \\
\hline Q14 & I am positive about age diversity in this workplace. \\
\hline
\end{tabular}


Table 5. Modified Operational Definition of construct for education background

\begin{tabular}{|l|l|}
\hline Q15 & The recruitment plan of the organization is based on the education background of the employees. \\
\hline Q16 & The organization provides paid study leave to employees who further their education. \\
\hline Q17 & $\begin{array}{l}\text { Opportunities for growth and advancement exist for employees who have lower qualification in } \\
\text { education. }\end{array}$ \\
\hline Q18 & The differences in education background do not encourage conflict. \\
\hline Q19 & At work, I experience lack of confidence due to my education background. \\
\hline Q20 & $\begin{array}{l}\text { The team leader includes all members at different education level in problem solving and } \\
\text { decision making. }\end{array}$ \\
\hline Q21 & The organization gives equal treatment when it comes to the diversity of education background. \\
\hline
\end{tabular}

Table 6. Modified Operational Definition of construct for employees performance

\begin{tabular}{|l|l|}
\hline Q22 & I enjoy my tasks and the division's work approach. \\
\hline Q23 & I am committed to the mission and direction of my organization. \\
\hline Q24 & I am motivated to complete the task that is assigned to me \\
\hline Q25 & I co-operate well with my colleagues. \\
\hline Q26 & Opposite gender can perform well and I enjoy working with them. \\
\hline Q27 & My performance level affects my salary level. \\
\hline Q28 & I am satisfied with my current salary level. \\
\hline Q29 & I am given the chance to try my own method of doing the job. \\
\hline Q30 & By learning more skills through courses/training, I can improve my task performance. \\
\hline Q31 & Good employee performance is important for the future growth of my organization. \\
\hline
\end{tabular}

Table 7. Gender of the Respondents

\begin{tabular}{|l|l|l|l|l|}
\hline Gender & Number & Frequency Percent & Valid Percent & Cumulative Percent \\
\hline Male & 149 & 49.7 & 49.7 & 100 \\
\hline Female & 151 & 50.3 & 50.3 & 100 \\
\hline Total & 300 & 100 & 100 & 100 \\
\hline
\end{tabular}

Table 8. Age of the Respondents

\begin{tabular}{|l|l|l|l|l|}
\hline Years Old & Number & Frequency Percent & Valid Percent & Cumulative Percent \\
\hline $20-29$ & 45 & 15 & 15 & 15 \\
\hline $30-39$ & 220 & 73.3 & 73.3 & 88.3 \\
\hline $40-49$ & 30 & 10 & 10 & 98.3 \\
\hline Over 50 & 5 & 1.7 & 1.7 & \\
\hline Total & 300 & 100 & 100 & 100 \\
\hline
\end{tabular}


Table 9. Education Level of the Respondents

\begin{tabular}{|l|l|l|l|l|}
\hline $\begin{array}{l}\text { Education } \\
\text { Level }\end{array}$ & Number & $\begin{array}{l}\text { Frequency } \\
\text { Percent }\end{array}$ & $\begin{array}{l}\text { Valid } \\
\text { Percent }\end{array}$ & $\begin{array}{l}\text { Cumulative } \\
\text { Percent }\end{array}$ \\
\hline None & 24 & 8 & 8 & 8 \\
\hline Diploma & 39 & 13 & 13 & 21 \\
\hline Degree & 177 & 59 & 59 & 80 \\
\hline Master & 56 & 18.7 & 18.7 & 98.7 \\
\hline PhD & 4 & 1.3 & 1.3 & \\
\hline Total & 300 & 100 & 100 & 100 \\
\hline
\end{tabular}

Table 10. Working Experience of the Respondents

\begin{tabular}{|l|l|l|l|l|}
\hline $\begin{array}{l}\text { Working } \\
\text { in Years }\end{array}$ & Number & $\begin{array}{l}\text { Frequency } \\
\text { Percent }\end{array}$ & $\begin{array}{l}\text { Valid } \\
\text { Percent }\end{array}$ & $\begin{array}{l}\text { Cumulative } \\
\text { Percent }\end{array}$ \\
\hline $2-5$ & 97 & 32.3 & 32.3 & 32.3 \\
\hline $6-10$ & 150 & 50 & 50 & 82.3 \\
\hline $10-15$ & 37 & 12.3 & 12.3 & 94.7 \\
\hline More than 15 & 16 & 5.3 & 5.3 & \\
\hline Total & 300 & 100 & 100 & 100 \\
\hline
\end{tabular}

Table 11. Position Level of the Respondents in the Organization

\begin{tabular}{|l|l|l|l|l|}
\hline Position Level & Number & Frequency Percent & Valid Percent & Cumulative Percent \\
\hline Senior Manager & 9 & 3 & 3 & 3 \\
\hline Manager & 11 & 3.7 & 3.7 & 6.7 \\
\hline Senior Executive & 28 & 9.3 & 9.3 & 16 \\
\hline Executive & 171 & 57 & 57 & 73 \\
\hline Entry Level & 81 & 27 & 27 & \\
\hline Total & 100 & 100 & 100 & 100 \\
\hline
\end{tabular}

Table 12. Coefficients

\begin{tabular}{|c|c|c|c|c|c|}
\hline & $\begin{array}{l}\text { Unstandardized } \\
\text { coefficients }\end{array}$ & $\begin{array}{l}\text { Unstandardized } \\
\text { coefficients }\end{array}$ & $\begin{array}{l}\text { Standardized } \\
\text { coefficients }\end{array}$ & & \\
\hline Model & Beta & Standard Error & Beta & $\mathrm{T}$ & $\begin{array}{l}\text { Significance } \\
\text { Level }\end{array}$ \\
\hline Constant & 2.574 & 0.18 & & 14.32 & 0.000 \\
\hline Gender Group & 0.29 & 0.043 & 0.36 & 6.78 & 0.000 \\
\hline Age Group & -0.174 & 0.039 & -0.315 & -4.436 & 0.000 \\
\hline $\begin{array}{l}\text { Education } \\
\text { Background } \\
\text { Group }\end{array}$ & 0.205 & 0.048 & 0.347 & 4.307 & 0.000 \\
\hline
\end{tabular}


Table 13. Ranking of Independent Variables based on Standardized Coefficient, Beta

\begin{tabular}{|l|l|l|}
\hline Independent Variables & $\begin{array}{l}\text { Standardized } \\
\text { Coefficients, Beta }\end{array}$ & Ranking \\
\hline Gender Group & 0.36 & 1 \\
\hline Education Background Group & 0.347 & 2 \\
\hline Age Group & -0.315 & 3 \\
\hline
\end{tabular}

Table 14. Summary of the Result of Hypotheses Testing

\begin{tabular}{|l|l|l|}
\hline Hypothesis & Supported & Not supported \\
\hline $\begin{array}{l}\text { There is significant relationship } \\
\text { between gender group and } \\
\text { employee performance. }\end{array}$ & $\begin{array}{l}\beta=0.333 \\
\mathrm{p}=0.000<0.01\end{array}$ & \\
\hline $\begin{array}{l}\text { There is no significant } \\
\text { relationship between age group } \\
\text { and employee performance. }\end{array}$ & & $\beta=-0.007$ \\
\hline $\begin{array}{l}\text { There is significant relationship } \\
\text { between education background } \\
\text { group and employees } \\
\text { performance. }\end{array}$ & $\beta=0.908>0.01$ \\
\hline
\end{tabular}

